Catherine M. Pickering Ralf C. Buckley

\title{
Swarming to the Summit
}

\author{
Managing Tourists at Mt Kosciuszko, Australia
}

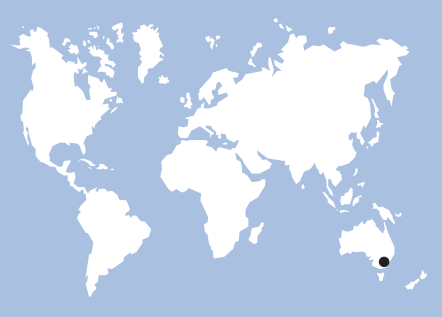

The iconic summer tourism destination in the Australian Alps National Parks is the summit area of continental Australia's highest mountain, Mt Kosciuszko. Currently 70,000 people visit the alpine area during the snow-free period each year, and about 21,000 of these take a day-walk to the summit and back. The environmental impacts of summer tourism include: soil compaction and erosion; introduction and spread of weeds; fecal contamination of lakes and creeks; increased feral animals; and vegetation clearance. The principal management responses have been: harden- ing of tracks; provision of toilets; education, including minimum-impact codes; and restrictions on activities such as camping in the catchment areas of glacial lakes. Currently, only the access tracks and immediate alpine area around the summit of $\mathrm{Mt}$ Kosciuszko receive so many visitors in such a small area. The summit area has become a honeypot focusing tourism and its impacts at one site. Effective management is needed to ensure that the summit along with the rest of the Kosciuszko alpine area remains viable for conservation and outdoor recreation.

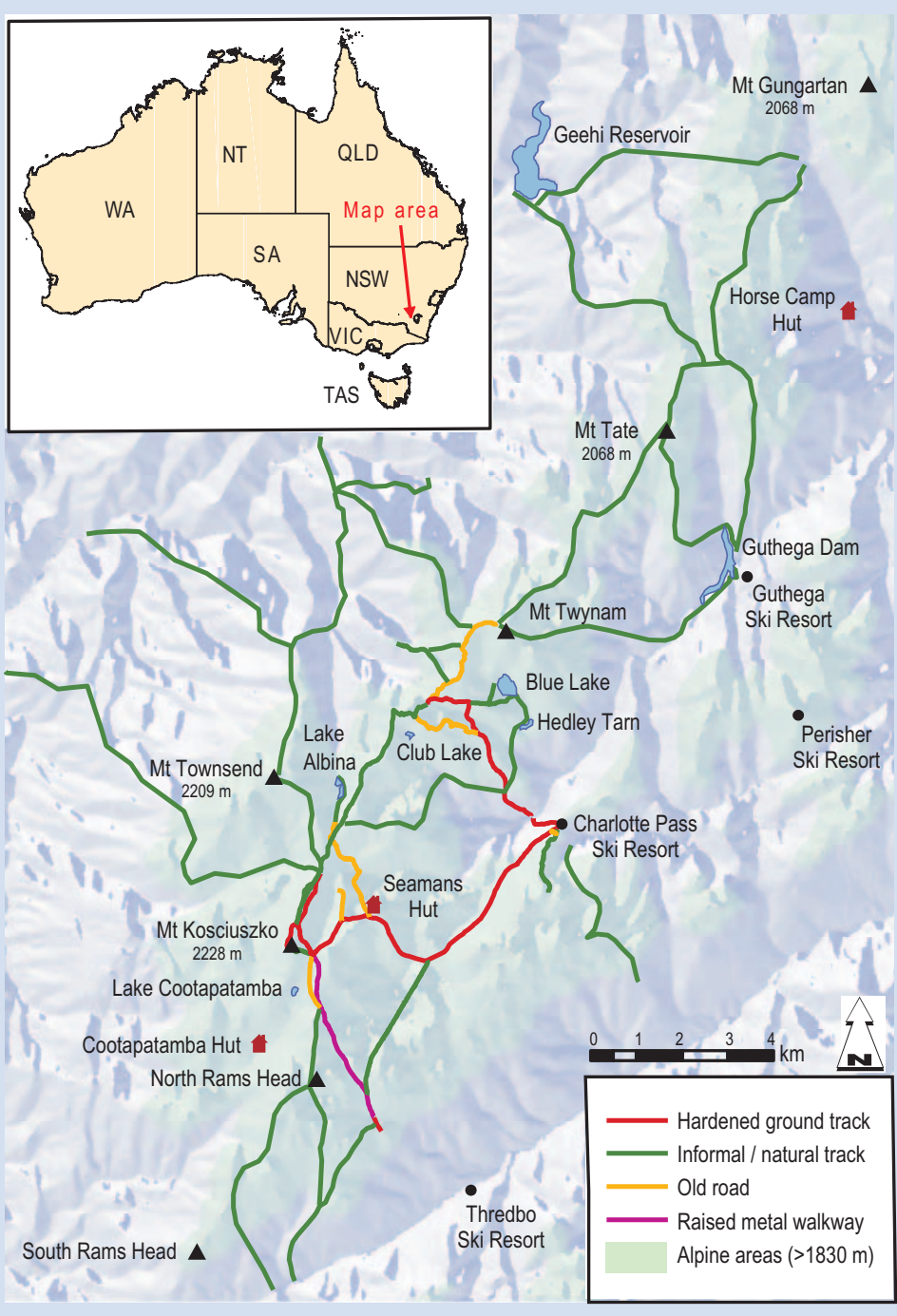

FIGURE 1 Maps of Kosciuszko National Park, showing the different types of tracks in the area. (Map by Pascal Scherrer and the NSWNPWS)

\section{The Kosciuszko alpine area}

Many mountain summits and adjacent areas worldwide are major tourist destinations, particularly those that are the highest peaks in a region. Besides being the highest mountain in continental Australia, Mt Kosciuszko (2228 $\mathrm{m}$ ) is by far the most accessible of the 7 continental summits: the peak is a half-day return walk from the nearest roadhead and resort. This popular iconic site is experiencing increasing levels of use, posing significant conservation challenges.

Alpine and subalpine vegetation occupy only a very limited area in Australia. Only $0.09 \%$ of the total area of the continent receives more than a month of snow, with just $5200 \mathrm{~km}^{2}$ above the treeline. Around $62 \%\left(15,000 \mathrm{~km}^{2}\right)$ of the mainland alpine and subalpine areas are protected within a contiguous series of reserves, known as the Australian Alps National Parks. Kosciuszko National Park (KNP) is the largest of these parks and receives over $75 \%$ of the estimated 1.5 million visitors to the Australian Alps each year. KNP is managed by the New South Wales National Parks and Wildlife Service (NSWNPWS).

Mt Kosciuszko and the associated peaks of the main range represent the largest contiguous alpine ecosystem in Australia (Figure 1). Most of the alpine terrain is relatively level or rolling ground. The area is of international biological and conservation significance, containing endemic and endangered species of animals and plants (Figure 2) including the anemone 


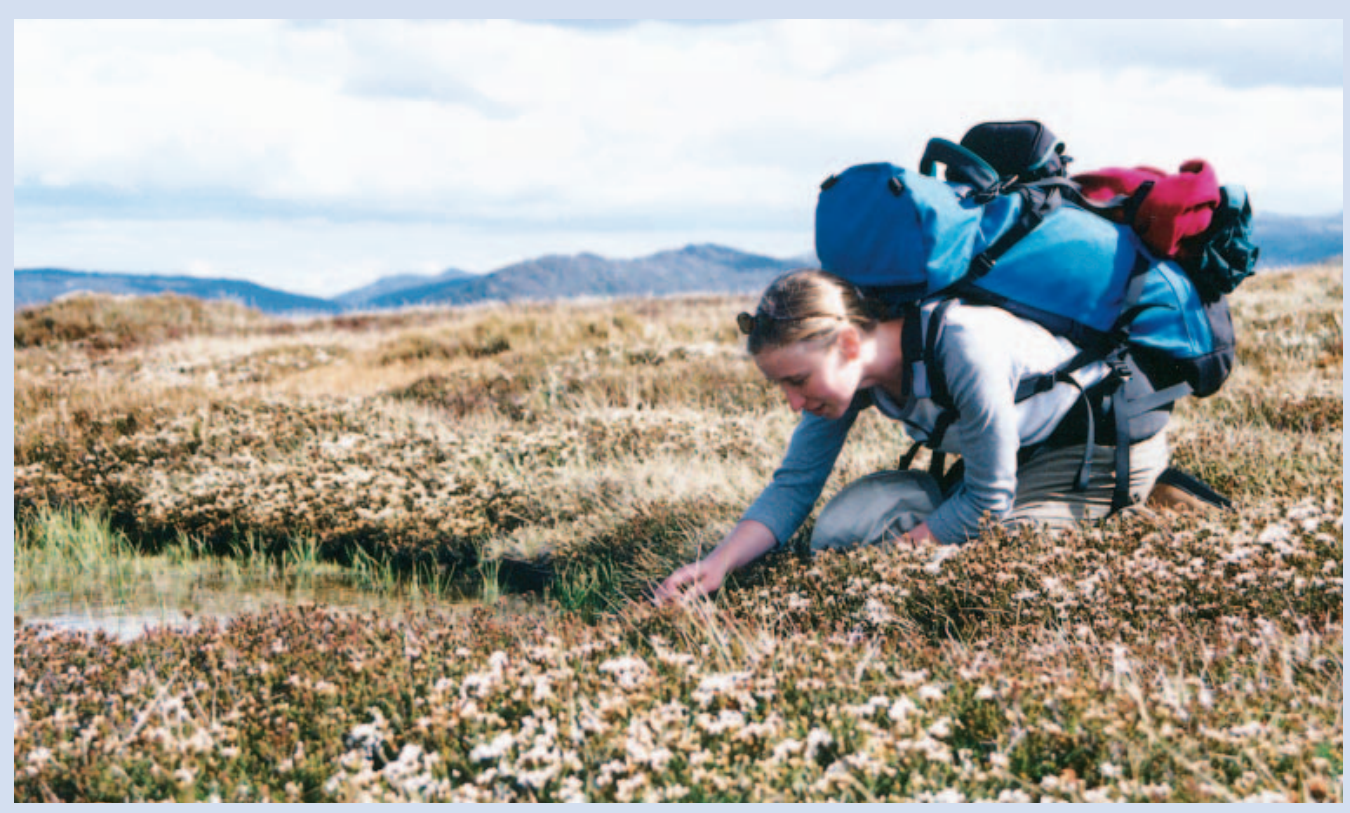

buttercup and the mountain pygmy possum. Currently the NSWNPWS is revising the 1982 Plan of Management for KNP including the management of tourists in the alpine area around Mt Kosciuszko.

\section{Tourism}

Ski resorts and downhill ski runs in the Australian Alps are largely in the steeper subalpine terrain, though the upper runs at some resorts are above the treeline. In the alpine zone, winter tourism and recreation includes backcountry snowboarding and cross-country skiing, and ice climbing at one or two sites.

In summer, short walks are the most popular activity, with over $80 \%$ of visitors during the snow-free period taking at least one day-walk. Sightseeing is also popular $(10 \%)$. Summer visitation to the area is increasing, with the number of visitors during the peak summer period from midDecember to the end of April estimated at 70,000 in 1999-2000. This compares with estimates of 20,000 summer visitors in the 1970 s and 36,000 in the 1980 s. The immediate summit of Mt Kosciuszko, an area of $100 \mathrm{~m}^{2}$ around the topographic peak, is the principal tourism hotspot visited by around 21,000 people each year. These figures include both commercial tour clients and independent travelers.

There are 2 main tourist access points to the Kosciuszko alpine area. Thirty-one percent of visitors walk along an old road from the Charlotte Pass roadhead $9 \mathrm{~km}$ away and $68 \%$ along a 6 -km raised walkway from the top of the Crackenback chairlift at Thredbo Village. Both these walking routes are relatively level but both are exposed to alpine weather. All but $2 \%$ of visitors to the alpine area stay within a diamond-shaped region $36 \mathrm{~km}^{2}$ in area, between Mt Kosciuszko, Crackenback, Charlotte Pass, and Blue Lake. Blue Lake is a popular day-walk destination reached by a hardened trail from Charlotte Pass (Figure 3). Most hikers reach the summit during a relatively brief period on peak days, typically between 1200 and $1330 \mathrm{~h}$. This leads to substantial physical crowding, especially because most visitors want to rest at the summit area, enjoy the view, and eat their lunch before returning (ie, they want an area where they can sit down, not simply walk by).

\section{Impacts and management response}

Tourism activities have had considerable negative environmental impacts on the alpine area. Impacts include: compaction of soil, erosion, vegetation trampling, fecal contamination of glacial lakes, disturbance to wildlife, noise pollution, reduction of visual amenities, and increased feral animal activity. Some infrastructure provided for tourism, such as walking tracks and huts, has also been
FIGURE 2 Bushwalker admiring flowering of Epacris (Southern Heaths). The stunning massed flowering of the heaths and herbs are part of the attraction of the region to visitors during the summer. Twenty-three species of plants are endemic to the Kosciusko alpine area out of 212 species of native ferns and flowering plants. (Photo by $\mathrm{CM}$ Pickering) 
FIGURE 3 Walking, be it for an hour, a day, or longer, is the most popular activity in the Kosciuszko alpine area, with $80 \%$ of visitors taking one of the popular walking tracks, such as this one to Blue Lake. (Photo by $\mathrm{CM}$ Pickering)

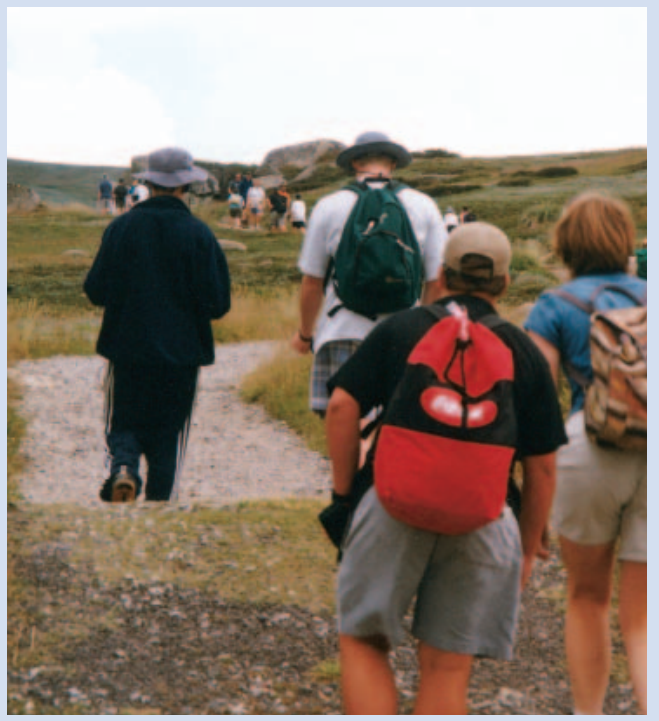

impacted by compaction of soil, clearing of vegetation, introduction of alien plants, and leaching of nutrients into adjacent areas. Impacts are particularly severe in the immediate summit area because of the concentration of use described above.

NSWNPWS manages KNP for both conservation and recreation. In response to increasing summer tourism, the park agency has progressively improved the sites within the alpine area by installing and upgrading toilets and walking tracks. In particular, tracks have been replaced by raised metal and wood walkways or hardened with gravel and geoweb. Horse riding and campfires are banned, with camping in the catchment areas of the glacial lakes restricted. Minimal-impact information is provided through signs and leaflets at visitor centers and throughout the alpine area.

\section{Management strategies: Honeypots or sacrifice areas?}

The concentration of visitors in the summit area of Mt Kosciuszko is causing negative impacts both on the natural environment and on visitor experience. NSWNPWS response focuses on site improvement, which concentrates use even further. The summit has become a tourism honeypot attracting high usage to a specific site within the park (Figure 4). Arguably, to some degree it has also become a sacrifice area, concentrating impacts at one site so as to protect other areas of high conservation value.

Sacrifice areas are found in many national parks worldwide. Most commonly, they have arisen through historical precedent, either at roadheads or trailheads or at scenic attractions. More rarely, they are established by management agencies as a deliberate technique to move visitors away from other areas that are overcrowded, easily affected, or have particular conservation value. Mountain peaks and summits run the risk of becoming sacrifice areas because they act as self-selecting focal points for visitors.

The value of sacrifice areas as a management strategy depends on the relative conservation value of the site and the effectiveness of local improvement in protecting the area. Some mountain summits are above the alpine zone and can be permanently snowbound so that even large numbers of visitors may produce little ecological impact except through litter and human waste. Mt Everest, Sagarmatha, is perhaps the prime example. Others, however, support vegetation communities, plants, and animals that may have limited distribution and high conservation value, which are easily disturbed by visitor noise and trampling. At Mt Warning in northern New South Wales, Australia, for example, NSWNPWS was forced to install a ring of raised metal walkways and lookouts around the entire summit to protect vegetation.

There are a number of significant risks associated with the use of $\mathrm{Mt}$ Kosciuszko as a honeypot, which deserve further study and additional management responses. Physical crowding of visitors during peak periods causes environmental impacts outside the immediate summit area as well as within it. During peak periods, visitors at the summit usually spill even into designated and marked rehabilitation areas. In addition, hikers leave the hardened trails at scenic lookout points. Spillover could be reduced by facilitating more even visitation patterns. This could be done by establishing a quota for the maximum number of people in a designated summit area at any one time. Queues and conflicts could be avoided by setting staggered starting slots for hikers 
FIGURE 4 Cars lined up on the side of the road at the Charlotte Pass roadhead during the busy summer holidays. The 2 main access points for the Kosciuszko alpine area are the roadhead at Charlotte Pass (31\% visitors) and the Crackenback chairlift at Thredbo Village (68\% of visitors). (Photo by CM Pickering)

to begin the walk on the most crowded days. One simple approach would be to introduce differential pricing of chairlift tickets, depending on the time of day.

Besides physically spilling from the summit area, visitors may initiate environmental impacts that spill beyond developed areas. These include introduction of weeds and pathogens and deposition of human wastes. The alpine lakes near Mt Kosciuszko have already suffered such contamination.

Perhaps the greatest environmental concern is the current upgrading of the gravel track from just below the summit of Mt Kosciuszko along the main range past Mt Carruthers to join up with track from Charlotte Pass to Blue Lake. The current informal path shows considerable damage including loss of vegetation and soil erosion. In response, NSWNPWS is replacing the track with gravel and geoweb. However, the use of such track material is problematic in itself. The track may also attract additional visitors and create additional honeypots.

The issues surrounding the use of the summit of Mt Kosciuszko for intensive tourism need to be addressed in the new Plan of Management for KNP. Environmentally sustainable management of tourism in the alpine area is a key issue because numbers of tourists and other visitors are continuing to grow, with existing infrastructure and management systems

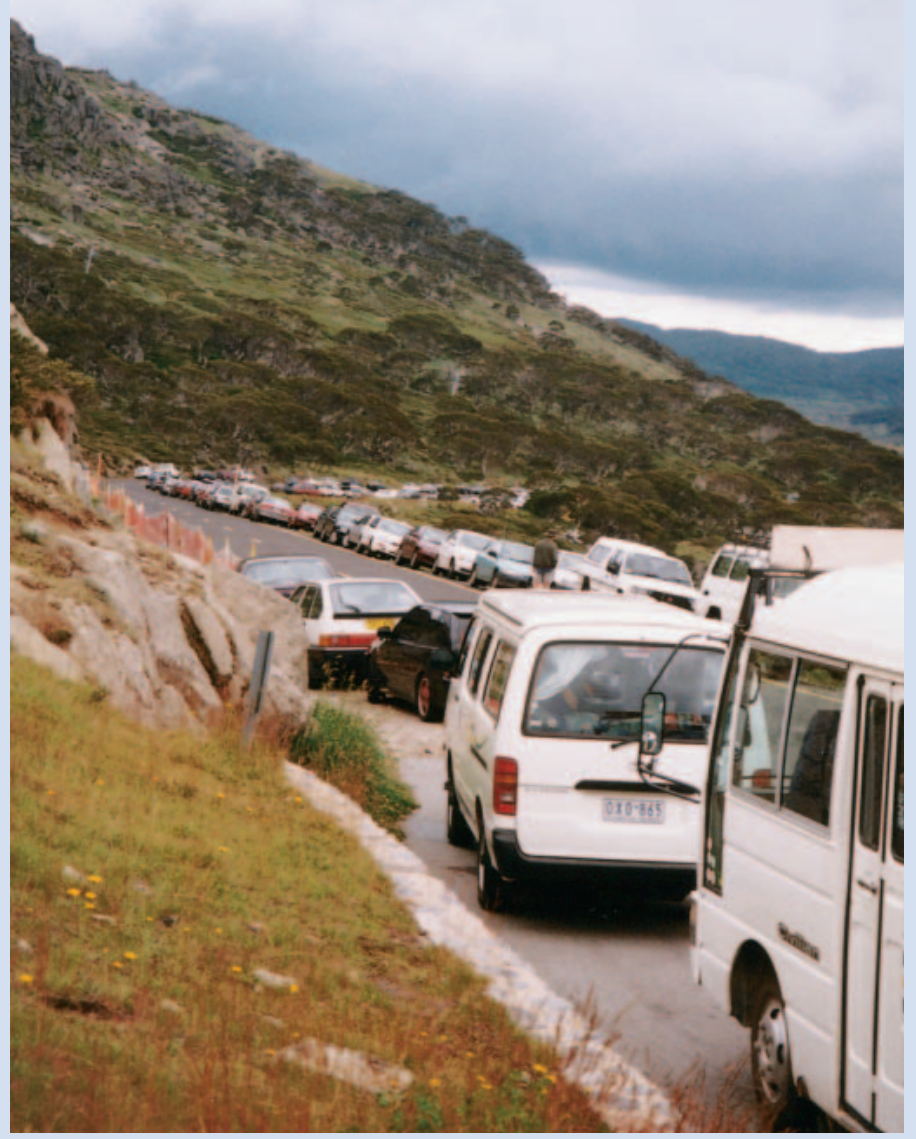

unable to contain them. If tourism to the Kosciuszko alpine area is to be environmentally sustainable, active management of the high use needs to be introduced as part of an overall visitor and conservation management strategy.

\section{ACKNOWLEDGMENTS}

Research in Kosciuszko National Park by Catherine Pickering and her graduate students has been supported over the past decade by the Australian National University (ANU), Griffith University, NSWNPWS, and CRCST. Ralf Buckley has been a volunteer research assistant for ANU staff, including Catherine Pickering. Comments by Graeme Worboys are gratefully acknowledged.

\section{AUTHORS}

\section{Catherine M. Pickering}

School of Environmental and Applied Sciences, Griffith University, Gold Coast Campus, PMB 50 Gold Coast Mail Centre, QLD 9726, Australia.

c.pickering@griffith.edu.au

Catherine Pickering is the leader of the Mountain Tourism subprogram for the Cooperative Research Centre for Sustainable Tourism, an interdisciplinary research team that is examining issues in the sustainability of mountain tourism. She has a long interest in research in the Australian Alps. Currently she is a Senior Lecturer at the School of Environmental and Applied Sciences, Griffith University.

\section{Ralf C. Buckley}

International Centre for Ecotourism Research, Griffith University, PBM 50 Gold Coast Mail Centre, QLD 9726 , Australia.

r.buckley@griffith.edu.au

Ralf Buckley is an ecologist specializing in the measurement and management of environmental impacts, particularly for outdoor tourism. He is Professor and Director of the International Centre for Ecotourism Research at Griffith University and Director of Nature and Adventure Tourism for Australia's Cooperative Research Centre for Sustainable Tourism.

\section{FURTHER READING}

Buckley RC, Pickering CM, Warnken J. 2000. Environmental management for alpine tourism and resorts in Australia. In: Goode PM, Price MF, Zimmermann FM, editors. Tourism and Development in Mountain Regions. New York: CABI International, pp 27-46.

Good RB. 1995. Ecologically

sustainable development in the Australian Alps. Mountain Research and Development 15:251-258.

\section{Pickering CM, Johnston S, Green K,}

Enders G. 2003. Impacts of tourism on the alpine area of Mt Kosciuszko. In: Buckley R, Weaver D, Pickering CM, editors. Nature Tourism and the Environment. New York: CABI International, pp 123-149.

Scherrer $\boldsymbol{P}$, Pickering $\boldsymbol{C}$. 2001. Effects of grazing, tourism and climate change on the alpine vegetation of Kosciuszko National Park. Victorian Naturalist 118:93-99.

Worboys G, Pickering CM. 2002. Managing mountain ecotourism at Kosciuszko. In: Taiwan Organising Committee for the Fourth Conference on the Protected Areas of East Asia, editor. Proceedings of the Fourth Conference on the Protected Areas of East Asia. IUCN World Commission on Protected Areas in East Asia Conference "Benefits Beyond Boundaries in East Asia" in Taipei, Taiwan, 18-23 March, 2002. Taipei: National Taiwan University Press, pp 145-178. 